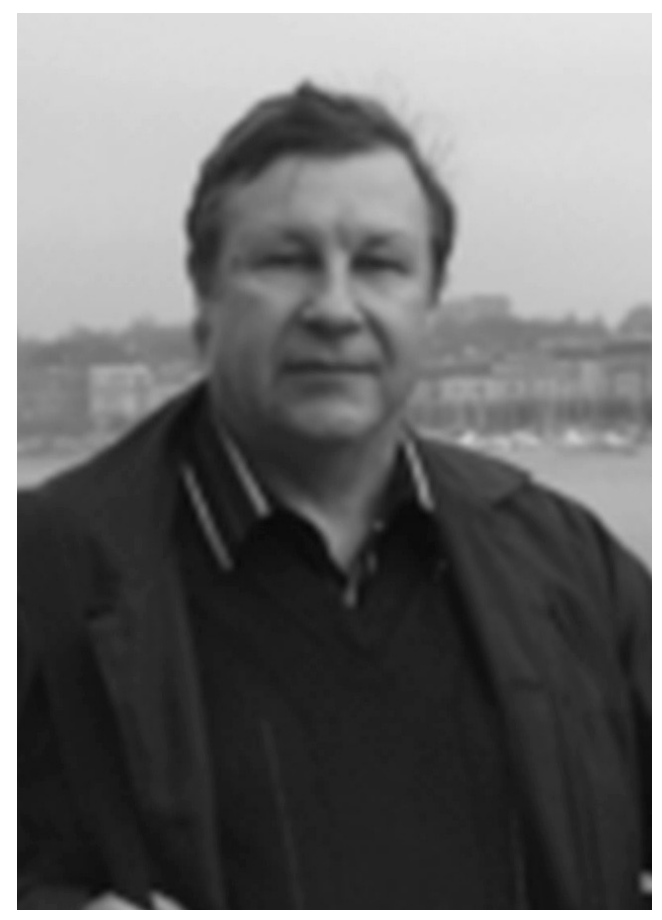

\section{УдК: 316.0}

DOI: https://doi.org/10.32689/2617-

2224-2020-1(21)-301-311

\section{Судаков Володимир Іванович,}

доктор сочіологічних наук, професор, завідувач кафедрою теорії та історії сочіології факультету соціології Київського національного університету імені Тараса Шевченка, 01601, м. Київ, вул. Володимирська, 58, тел.: +38 (067) 50286 48, e-mail:vlsudakov@ukr.net

ORCID: 0000-0002-2032-1093

\section{Судаков Владимир Иванович,}

доктор социологических наук, профессор, заведующий кафедрой теории и истории социологии факультета социологии Киевского национального университета имени Тараса Шевченко. Украина, 01601, 2. Киев, ул. Владимирская, 58, тел.: +38 (067) 50286 48,e-mail:vl_sudakov@ukr. net

ORCID: 0000-0002-2032-1093

Sudakov Volodymyr Ivanovich, Professor, Doctor of Sociological Science, Head of the Theory and History of Sociology dpt., Faculty of Sociology, Taras Shevchenko National University of Kyiv, 01601, Kyiz, Str. Volodymyrska, 58, tel.: +38 (067) 5028648 e-mail:vl_sudakov@ukr.net

ORCID: 0000-0002-2032-1093

\title{
АРХЕТИПИ КУЛЬТУРИ ТА СУБКУЛЬТУРИ ЯК ДЕТЕРМІНАНТИ СОЦІАЛЬНИХ ДІЙ ТА СОЦІАЛЬНОГО УПРАВЛІННЯ
}

Анотація. Аргументовано, що процеси глобалізації культури є важливим стимулом розвитку наукових досліджень сучасної культури, іï функціональної та технологічної специфіки. Підкреслено, що культурний розвиток людської цивілізації завжди реально обумовлювався впливом різних субкультур. Саме тому особливе значення набувають спеціалізовані наукові дослідження, спрямовані на обгрунтування архетипного статусу культури та субкультури як детермінант соціальних дій та соціального управління. Надано докази активного використання вченими таких понять, як “глобальна культура”, “мультикультуралізм”, “транскультуралізм”, “міжкультурна комунікація” “культур- 
ний капітал”, “субкультурний капітал”, “субкультурний життєвий стиль” є позитивним чинником розробки інноваційних наукових програм аналізу онтологічної специфіки архетипів культури та субкультури в контексті тенденцій глобалізації, віртуалізації та індивідуалізації суспільного життя. Визначено суперечності конфліктологічної інтерпретації субкультури як “культури соціальної меншості”, поява якої спричинена такими соціальними явищами як соціальне відчуження, маргіналізація та бідність. Автор визначає архетип субкультури як поліфункціональне соціальне явище, що виникає та відтворюється в суспільстві як атрибутивний наслідок культурної диференціації. Аргументовано, що важливою інноваційною проблемою соціального менеджменту є розробка технологій ефективного соціального контролю різних форм активності субкультурних груп, приймаючи до уваги ту обставину, що ця активність демонструє як критичне ставлення людей до існуючого соціального порядку, так і є виразом креативних цінностей соціального конструктивізму.

Ключові слова: культура, субкультура, архетипи культури та субкультури, глобальна культура, транскультуралізм, міжкультурна комунікація, культурний капітал, субкультурний капітал, субкультурний життєвий стиль, соціальне управління.

\section{АРХЕТИПЫ КУЛЬТУРЫ И СУБКУЛЬТУРЫ КАК ДЕТЕРМИНАНТЫ СОЦИАЛЬНЫХ ДЕЙСТВИЙ И СОЦИАЛЬНОГО УПРАВЛЕНИЯ}

Аннотация. Аргументировано, что процессы глобализации культуры являются важным стимулом развития научных исследований современной культуры, ее функциональной и технологической специфики. Подчеркнуто, что культурное развитие человеческой цивилизации всегда реально было обусловлено определенным влиянием различных субкультур. Именно поэтому особую значимость приобретают специализированные научные исследования, направленые на обоснование архетипного статуса культуры и субкультуры как детерминант социальных действий и социального управления. Представлены доказательства, что активное использование учеными таких понятий, как “глобальная культура”, “мультикультурализм”, “транскультурализм”, “интеркультурная коммуникация”, “культурный капитал”, “субкультурный капитал”, “субкультурный жизненный стиль” являются позитивным фактором разработки инновационных научных програм анализа онтологической специфики архетипов культуры и субкультуры в контексте тенденций глобализации, виртуализации и индивидуализации общественной жизни. В статье обращено внимание на противоречия конфликтологической интепретации субкультуры как “культуры социального меншинства”, возникновение которой обусловлено такими социальными явлениями как социальное отчуждение, маргинализация и бедность. Автор определяет архетип субкультуры как полифункциональное социальное явление, которое возникает и воспроизводится в обшестве как атрибутивное последствие культурной дифференциации. Аргументировано, что актуальной инноваци- 
онной проблемой социального управления является разработка технологий эффективного социального контроля различных форм активности субкультурных груп, принимая во внимание то обстоятельство, что эта активность демонстрирует как критическое отношение людей к существующему социальному порядку, так и является выражением креативных ценностей социального конструктивизма.

Ключевые слова: культура, субкультура, архетипы культуры и субкультуры, глобальная культура, транскультурализм, интеркультурная коммуникация, культурный капитал, субкультурный капитал, субкультурный жизненный стиль, социальное управление.

\section{THE FRCHETYPES OF CULTURE AND SUBCULTURE AS THE DETERMINANTS OF SOCIAL ACTIONS AND SOCIAL MANAGEMENT}

Abstract. The conceptual argumentation that the processes of the cultural globalization are important stimuli for development of scientific studies of the contemporary culture and its functional and technological peculiarities is presented in the article. It is underlined that the cultural development of the human civilization has always been stimulated by the influence of different subcultures. Therefore the specialized scientific investigations, which are oriented to the substantiation of the archetypal status of culture and subculture as the determinative factors of social actions and social management today, are very important. It is proved that active use of such concepts as "global culture", "multiculturalism", "transculturalism", "intercultural communication", "cultural capital", "subcultural capital", "subcultural lifestyle" by scholars now is the positive factor for the creation of scientific programs for analysis of the ontological specifics of the archetypes of culture and subculture in the context of globalization, virtualization and individualization of social life. Attention is paid to the contradictions of the conflict interpretation of subculture as the culture of social minority" that is caused by such social phenomena as social alienation, marginalization and poverty. The author defines the archetype of subculture as the multifunctional social phenomenon that emerges and reproduces itself in society as the attributive consequence of the cultural differentiation. It is argued that the significant innovative problem of the social management is the elaboration of the effective technologies for social control over different forms of activities of subcultural groups that emerge as critical human attitudes to the existing social order and as the creative values of the progressive social constructivism.

Key words: culture, subculture, archetypes of culture and subculture, global culture, multiculturalism, transculturalism, intercultural communication, cultural capital, subcultural capital, subcultural lifestyle, social management.

Постановка проблеми. Відомо, що в сучасних соціальних науках те- оретичної та практичної значущості набули фундаментальні та прикладні 
дослідження, пов'язані з вивченням інноваційних тенденцій соціокультурних змін, культурної диференціації та технологічного потенціалу культури. Вочевидь, інноваційні процеси глобалізації культури суттєво ускладнюють завдання наукового розуміння як самого феномену культури, так і їі функціональної та технологічної специфіки. Тому переважна більшість науковців загалом підкреслює важливість уточнення змісту категорії “культура” як фундаментального поняття соціальної філософії та соціальної теорії, оскільки усталене загальне розуміння культури як комплексу досягнень людства за весь період свого історичного розвитку є надмірно абстрактним і не вказує, по-перше, на універсальні структурні характеристики культури та особливості динаміки їі історичних змін, які відбувалися під впливом різних субкультур. По-друге, варто також звернути увагу і на ту важливу обставину, що людська культура завжди формувалась і розвивалась як система практик соціального управління, яке здійснювалось в певних режимах владного впливу одних соціальних суб'єктів стосовно інших. Необхідно зазначити, що різноманітні спроби вчених здійснення формального узагальнення певних атрибутивних онтологічних ознак культури як культурних універсалій на даний час не можна визнати як такі, що сприяють розвитку спеціалізованих наукових програм дослідження культури як соціального явища та процесу детермінації соціальних дій індивідуальних та колективних суб'єктів суспільного життя. Введення у науковий обіг таких понять, як “глобальна культура”, “мультикультуралізм”, “транскультуралізм”, “міжкультурна комунікація”, “культурний капітал”, “субкультурний капітал”, “субкультурний життєвий стиль” певним чином стимулює вчених до дослідження проблеми наукового аналізу онтологічної специфіки архетипів культури та субкультури в контексті тенденцій глобалізації, віртуалізації та індивідуалізації суспільного життя. Саме тому мета автора даної статті полягає у здійсненні аналізу та узагальнення концептуальної аргументації як стимулу подальших досліджень означеної проблеми.

Аналіз останніх досліджень і публікацій. Дослідження феноменів культури та субкультури в сучасних соціальних науках загалом засвідчує про певні пізнавальні труднощі визначення пізнавального статуту понять “культура" та субкультура". В наукових працях вчених [1-3] підкреслюється важливість вивчення нових тенденцій культурних змін, які засвідчують зростання ролі культурних практик в глобальному розвитку людства. Саме тому особливої наукової значущості набувають праці, які спрямовані на обгрунтування архетипного статусу культури та субкультури як детермінант соціальних дій та соціального управління [4-6]. Також важливим науковим напрямком стає вивчення креативного потенціалу субкультур як фундаментальних онтологічних стимулів соціальних змін [7-10]. Водночас у працях вітчизняних вчених [11-15]. констатована необхідність розвитку інноваційних технологій соціального управління, оскільки стихійні процеси культурних змін реально є чинни- 
ками посилення соціальної напруженості та конфліктних взаємодій.

Виклад основного матеріалу. Насамперед, слід зазначити, що загальний зміст сучасних досліджень проблем культури відображає ситуацію необхідності створення нових фундаментальних теорій культури та культурного розвитку. На цю обставину справедливо звертають свою увагу багато вчених, підкреслюючи що поняття “культура" в новітніх інтерпретаціях є поняттям, яке фіксує лише найважливіші атрибутивні властивості і якості, які властиві суспільному життю та людській поведінці. “Соціологи та антропологи використовують це поняття в якості узагальнюючої категорії, яка відображує символічні, небіологічні, тобто набуті аспекти життя людського суспільства. Культура включає мову, звичаї та узгоджені традиції (конвенціiі), за допомогою яких можна відрізнити людську поведінку від поведінки інших приматів” [1, с. 99].

На думку К. Кемейєра, Дж. Рітцера та Н. Стмена при визначенні поняття “культура" важливо враховувати архетипний соціальний статус цього поняття, яким позначаються найважливіші умови колективного життя людей. "Культура - це всеохоплюючий комплекс ідей та матеріальних об'єктів, які люди певного суспільства (або групи) створили та пристосували до для задоволення необхідних потреб колективного життя" [4, с. 85]. Вчені вважають, що таке визначення сприяє подальшому розвитку інноваційних досліджень різних моделей поведінки людей, феноменів культурного релятивізму та етноцетризму, функціональної ролі знань, символів та вірувань а також норм, “як засобів управління повсякденною поведінкою” [4, с. 86].

Вочевидь, що інших вчених не задовольняє загальна перспектива такої дослідницької стратегії. Так К. Келхоун, Д. Лайт та С. Келер пропонують більш “вузьке” загальне визначення культури, шляхом ідентифікації їі атрибутивних складових як культурних універсалій: “Культура - це мова, норми, цінності знання та символи, які формують певний спосіб життя. Культура є розумінням дій окремих людей, які поділяються 3 іншими людьми заради забезпечення стабільного самовідтворення певної групи" [5, с. 7].

Важливо підкреслити, що дане визначення також доволі чітко фіксує архетипний соціальний статус поняття культури. Водночас слід вказати, що певною перевагою такого більш "вузького" тлумачення змісту даного поняття є те, що вчені пропонують досліджувати власне соціальні онтологічні характеристики культури в контексті з'ясування ii. зв'язку 3 іншими атрибутивними властивостями суспільного життя, які позначаються трьома такими відомими поняттями, як “соціальна дія”, “функціональна інтеграція”, та “влада”. Таку дослідницьку стратегію слід визнати як перспективну для подальшого розвитку, оскільки вона загалом сприяє спеціалізованому диференційованому вивченню питань 1) культурної інтеграції; 2) культурного багатоманіття та субкультур; 3) культурної репродукції; 4) зв’язку культури та медіа; 5) інтернаціоналізації та глобалізації культури [5, c. 86]. 
Близьку точку зору формулює i Г. Бехман, який визначає культуру як рефлексивну форму людського досвіду [6, с. 109-117]. Цей вчений стверджує, що сучасне поняття культури має рефлексивне значення та базується на порівнянні. “Культура - це те відмінне, що визначає спосіб життя людей, а це створює передумови для порівняння. Тобто культура - це те, що уможливлює порівняння того, що не може бути порівняним: спосіб життя. При цьому горизонт спостереження розгортається як регіонально, так і національно, та забезпечує, насамперед, історичну глибину відмінностей. Культура як рефлексивна форма створює дистанцію до усього чужого, проте водночас дозволяє ще доволі далекому та відстороненому наближатись до суспільства у якості чужої культури” [6, с. 111].

Примітно, що Г.Бехман намагається уникнути суто формального опису соціальних функцій сучасної культури, яка, на його думку, має єдину функціональну спрямованість, що доцільно позначити у трьох виміpax:

- по-перше, культура має особливе значення для формування та розвитку людини як особистості, вона є системою загальноприйнятих звичаїв в певному суспільстві, які відрізняються від звичаїв інших суспільств та культур;

- по-друге, культура є значущою чеснотою, що фіксує відмінність власне між культурою та простим буденним існуванням людей; у такому виразі культура виступає як очищення життя та позначає їх соціальний розподіл на “вимоку культуру" та “масову культуру";
- по-третє, культура поділяє суспільство на історичні епохи - вона дозволяє людям, кинувши погляд на минуле визначити чинники прогресу в ставленні до природи та здійснити оцінку прогресивних змін в існуючій системі суспільних відносин [6, c. 111-112].

Вочевидь, що таке розуміння функціональної спрямованості сучасної культури вказує на таку ii атрибутивну властивість як змагальний характер. Відомо, що в умовах глобалізації суттєво посилюється конкуренція між культурами, прояви якої різним чином пояснюються в соціологічних теоріях глобальної модернізації та глобальної залежності. Однак, доцільно вказати, що звертаючи увагу на важливості дослідження феномену конкурентоздатності сучасних культур, Г. Бехман недооцінює ту важливу обставину, що культура як втілення результативних тенденцій суспільно-історичної практики є значущим ресурсним фактором легітимації і технологізації систем соціальних дій та соціальних претензій індивідуальних та колективних суб'єктів суспільного життя, що є важливим джерелом виникнення й існування різноманітних субкультур.

Зосереджуючи увагу на з'ясуванні гносеологічних особливостей категоpiї “субкультура”, важливо підкреслити необхідність подолання спрощених трактувань субкультури як специфічного онтологічного різновиду культури - "культури соціальної меншості”, поява якої спричинена такими соціальними явищами як соціальне відчуження, маргіналізація та бідність . 
На дану обставину звертає свою увагу П. Вільямс у монографії “Субкультурна теорія. Традиції та Концепти” [7]. У даній праці констатовано, що сучасних дослідників вже не задовольняє образ суспільства, якому притаманна певна домінуюча культура з різними дисфункціональними субкультурнимми елементами, оскільки сучасні розвинуті суспільства скоріш являють собою набір різних за своїми інтересами соціальних груп, члени яких взагалі не бажають говорити про будь-які субкультури. На думку П. Вільямса поняття “субкультура" відображує не лише певну систему гуманітарних цінностей нон-конформізму, супротиву, протесту, свободи вибору, самовиразу, які певними чином формують та характеризують критичне ставлення людей до існуючого соціального порядку. Важливо також враховувати, що це поняття є специфічним виразом цінностей соціального конструктивізму як стимулів соціального прогресу. Тому перспективи розробки наукової субкультурної теорії слід пов’язувати з творчим осмисленням наступних питань: “Шо є і що не субкультурним? Іншими словами, як встановити межі субкультур, як вони виникають та зникають? I яким чином ми можемо знайти відповіді на ці питання" [7, с. 6].

Варто зазначити, що Р. Гейєнфлер у своїй праці [8] підкреслює креативну здатність субкультур до формулювання альтернативних поглядів людей стосовно усталеного способу свого життя. "Наявність саме таких альтернативних поглядів зумовлює потребу в ретельному вивченні і кращому розумінні мотивацій, думок та практик субкультурних груп" [8, c. 3]. У даній праці авторкою здійснена наукова аргументація важливості врахування більш широкого спектру концептуальних проблем, спеціалізоване дослідження яких сприятиме визначенню епістемологічних принципів субкультурного аналізу. Вона виділяє та аналізує зміст 8-ми наступних фундаментальних проблем:

1. Що являють собою субкультури?

2. Як виникають субкультури та чому люди приймають в них участь?

3. Яким чином субкультури чинять супротив "мейнстріму" суспільства та чи є вони загалом успішними?

4. Хто є учасниками субкультурних практик?

5. Хто є “аутентичними” учасниками і хто є "випадковими” учасниками?

6. Яким чином суспільство реагує та субкультури?

7. Чи стають зараз субкультури віртуальними та глобальними?

8. Що відбувається з субкультурами у разі зростання їх соціального впливу?

Вочевидь, що увага вчених до подальшого наукового вивчення зазначених проблем з метою визначення нових функціональних характеристик сучасних субкультур потребує використання пізнавального потенціалу деяких важливих понять. Так Дж. Льюіс вказує на важливість більш широкого використання поняття “транскультуралізм”, яким можливо пояснити певні режими зростання глобального впливу різних субкультурних соціальних рухів [2]. На думку К. Сорелз для пояснення таких режимів доцільно також 
використовувати поняття "міжкультурна комунікація” [3]. Ефективне використання пізнавального потенціалу даних понять, як демонструє праця В. Лапіної [11], сприяє розумінню тенденції глобального поширення субкультурних практик такого культурно-ідеологічного явища, як консьюмеризм.

Відома британська дослідниця С. Торнтон з метою вивчення процесу інтерналізації культурних норм, яким, на ii думку, визначається креативний потенціал різних субкультур пропонує ввести у науковий обіг поняття “субкультурний капітал” [9, c. 200-208].

Розвиваючи дану позицію, Д. Гебдайж у монографії "Субкультура: розуміння стилю (нові акценти)” [10] вказує, що у будь-якій культурі класового суспільства певним чином втілюється ідеал “естетичної досконалості”. Різноманітні практичні способи онтологізації даного ідеалу породжують різні “субкультурні життєві стилі”, які можуть мати виразні як функціональні, так і дисфункціональні прояви. Примітно, що функціональність субкультурних стилів вчений визнає як важливу атрибутивну рису суспільного життя. Тому, на його думку, різноманітні контркультури (counter cultures) зараз взагалі недоцільно розглядати як субкультури в силу соціальної локальності самих контркультур (як ціннісного виклику невеликої частини молоді середнього класу) [10, c. 2-7].

Зазначенні пропозиції загалом вказують на важливість концептуального розуміння субкультури як архетипного поліфункціональ- ного феномену суспільного життя, який стабільно відтворюється у суспільствах як соціально-історичних системах різного типу внаслідок процесу диференціації культурних практик індивідуальних та колективних суб'єктів суспільного життя.

Водночас слід звернути увагу, що на даний час питання розробки технологій управління процесами соціальної активності субкультурних груп має важливе значення не лише для наукових досліджень, але й для модернізації регулятивних функцій політичних інститутів. Так Дж. Льюiс вважає, що використання методології транскультуралізму дозволяє визначити відмінності між гуманістичними, антигуманістичними та постгуманістичними технологіями [2, с. 22]. Сам вибір та ефективне використання цих технологій залежить від наукових від валідності оцінок стану та можливих деструктивних наслідків соціальної напруженості та протестної активності різних соціальних груп.

Варто вказати, що у працях вітчизняних вчених також підкреслюється необхідність розвитку інноваційних технологій соціального управління, оскільки стихійні процеси культурних змін реально є чинниками посилення соціальної напруженості та конфліктних взаємодій і комунікацій. Тому, оцінюючи результати проведених досліджень, слід вказати, що важливими напрямками наукової роботи є: 1) з'ясування особливостей активності молодіжних субкультурних груп в містах України [12]; 2) розробка концептуальної моделі та емпіричних показників культурних детермінант соціальної 
напруженості та протестної поведінки в регіонах України [13]; 3) аналіз процесу трансформації соціальних дій субкультурних груп українського суспільства [14]; 4) ідентифікація та характеристика дисфункціональних соціальних наслідків, які пов'язані 3 низькою ефективністю демократичних реформ [15].

Висновки та перспективи подальших досліджень.

1. Процеси глобалізації культури є важливим стимулом розвитку наукових досліджень сучасної культури, їі функціональної та технологічної специфіки. Культурний розвиток людської цивілізації завжди обумовлювався впливом різних субкультур. Нові тенденції культурних змін засвідчують про зростання ролі культурних практик як чинників організації соціального порядку різних суспільств. Саме тому важливе значення мають спеціалізовані наукові дослідження, що спрямовані на обгрунтування архетипного статусу понять “культура" та “субкультура" як детермінант соціальних дій та соціального управління.

2. Активне використання вченими таких понять, як "глобальна культура”, “мультикультуралізм”, “транскультуралізм”, “міжкультурна комунікація”, “культурний капітал”, “субкультурний капітал”, “субкультурний стиль” є позитивним чинником розробки інноваційних наукових програм аналізу онтологічної специфіки архетипів культури та субкультури в контексті тенденцій глобалізації, віртуалізації та індивідуалізації суспільного життя.

3. Важливою інноваційною проблемою соціального менеджменту є розробка технологій ефективного соціального контролю різних форм активності субкультурних груп. Необхідно розуміти, що ця активність демонструє як критичне ставлення людей до існуючого соціального порядку, так і є виразом цінностей соціального конструктивізму як стимулів соціального прогресу.

\section{СПИСОК ВИКОРИСТАНИХ ДЖЕРЕЛ}

1. Culture // Abercombie N., Hill St, Turner Br. The Pinguine Dictionary of Sociology. - Third ed. London: Pinguine books Ltd., 1994. P. 99.

2. Lewis J. From Culturalism to Traansculturalism // Iowa Journal of Cultural Studies., 2002. N1 ( spring). P. 14-32.

3. Sorrels K. Intercultural communication, Globalization and Social Justice / Katryn Sorrels. Thousand Oaks, California: Sage publ., 2013. 290 p.

4. Kammeyer K., Ritzer G., Yetman N. Sociology: experiencing changing societies. Boston: Allyn \& Bacon, 1997. 650 p.

5. Kelhoun Cr., Light D., Keller S. Sociology. 6th ed. New York: Mc Graw Hill, 1994. 651 p.

6. Бехманн Г. Современное общество: общество риска, информационное общество, общество знаний / Готтхард Бехманн; пер. с нем. А. Ю. Антокольского, Г. В. Гороховой, Д. В. Ефременко, В. В. Каганчук, С. В. Месяц. 2-е изд., М.: Логос, 2012. 248 с.

7. Williams P. Subcultural Theory. Traditions and Concepts. Cambrige: Polity Press, 2011. 224 p.

8. Haenfler R. Subcultures: The basics. New York: Routlege, 2014. 192 p.

9. Thornton S. The Sociologic of Subcultural Capital // The Subcultures Reader / K.Geldner and S.Thornton (eds). L.- N.Y: Routlege, 1997. P. 200-212. 
10. Hebdige D. Subculture: The Meaning of Style (new accents). L.: Routlege, 2002. 286 p.

11. Lapina V. V. The archetype of consumption and its contradictions in the contemporary European space of economic and social interactions / V. V. Lapina // Public management : collection. № 4 (14). June 2018. \Kyiv: ДП “Видавничий дім "Персонал”, (Special edition). P. 159-170.

12. Sub/культуры: протест, коммуникация или обретение себя? Херсон: ФЛП Грань Д.С., 2016. 239 с.

13. Соціальна напруженість в регіональних вимірах: проблеми теорії, методології та методики соціологічного дослідження: Монографія / В. І. Судаков, С. В. Сірий, В. В Лапіна та ін.; за заг. В. І. Судакова. К.: Логос, 2018. 197 с.

14. Субкультурна віріативність українського соціуму / за ред. Н. Костенко, А. Ручки. К.: Ін-т соціології НАН України, 2010. 288 с.

15. Шульга М. Збій соціальної матриці: монографія / Микола Шульга. К.: Ін-т соціології НАН України, 2018. $284 \mathrm{c}$.

\section{REFERENCES}

1. Abercombie, N., Hill, S., Turner, B. (1994). Culture. The Pinguine Dictionary of Sociology. (3rd ed.). (p. 99). London: Pinguine books Ltd [in English].

2. Lewis, J. (2002). From Culturalism to Transculturalism. Iowa Journal of Cultural Studies, 1, 14-32 [in English].

3. Sorrels, K. (2013). Intercultural communication, Globalization and Social Justice. Thousand Oaks, California: Sage publ. [in English].

4. Kammeyer, K., Ritzer, G., Yetman, N. (1997). Sociology: experiencing changing societies. Boston: Allyn \& Bacon [in English].
5. Kelhoun, C., Light, D., Keller, S. (1994). Sociology. (6th ed.). New York: Mc Graw Hill [in English].

6. Bekhmann, G. (2010). Sovremennoe obshchestvo: obshchestvo riska, informatsionnoe obshchestvo, obshchestvo znaniy [Modern society: risk society, information society, knowledge society]. (A. Yu. Antokolskiy, G. V. Gorokhovyy, D. V. Efremenko, V. V. Kaganchuk, S. V. Mesyats, Trans). (2nd ed.). Moscow: Logos [in Russian].

7. Williams, P. (2011). Subcultural Theory. Traditions and Concepts. Cambrige: Polity Press [in English].

8. Haenfler, R. (2014). Subcultures: The basics. New York: Routlege [in English].

9. Thornton, S. (1997). The Sociologic of Subcultural Capital. The Subcultures Reader. K. Geldner and S. Thornton (Eds.). (pp. 200-212). London; New York: Routlege [in English].

10. Hebdige D. (2002). Subculture: The Meaning of Style (new accents). London: Routlege [in English].

11. Lapina, V. V. (2018). The archetype of consumption and its contradictions in the contemporary European space of economic and social interactions. Public management, 4(14), 159-170 [in English].

12. Gran, D. S. (2016). Sub/kultury: protest, kommunikatsiya ili obretenie sebya? [Sub/culture: protest, communication or gaining oneself?]. Kherson: FLP [in Russian].

13. Sudakov, V. I., Siryi, Ye. V., Lapina, V. V., Saveliev, Yu. B., Chernykh, H. A., Kondov, K. V., Nakhabich, M. A. (2018). Sotsialna napruzhenist $\mathrm{v}$ rehionalnykh vymirakh: problemy teorii, metodolohii ta metodyky sotsiolohichnoho doslidzhennia [Social tensions in regional dimensions: problems of theory, methodology and methodology of so- 
ciological research]. Kyiv: Lohos [in Ukrainian].

14. Kostenko, N., Ruchka, A. (Eds.). (2010). Subkulturna viriatyvnist ukrainskoho sotsiumu [Subcultural virativity of the Ukrainian society].
Kyiv: In-t sotsiolohii NAN Ukrainy [in Ukrainian].

15. Shulha, M. (2018). Zbii sotsialnoi matrytsi: monohrafiia [The failure of the social matrix]. Kyiv: In-t sotsiolohii NAN Ukrainy [in Ukrainian]. 